\title{
PREFERENSI PENGGUNAAN MATERIAL PADA ATAP RUMAH TINGGAL
}

(Roof Material Preferences for Housing)

\author{
Dindha Nirmalasari'1); Irma H. Lubis ${ }^{2)}$; Hanson E. Kusuma'); M. Donny Koerniawan ${ }^{2)}$ \\ 1) Program Magister Arsitektur Institut Teknologi Bandung \\ 2) Sekolah Arsitektur, Perencanaan, dan Pengembangan Kebijakan Arsitektur \\ Institut Teknologi Bandung \\ Jl. Ganesha No.10, Lb. Siliwangi, Coblong, Kota Bandung, Jawa Barat \\ dindhanirmala@gmail.com
}

\begin{abstract}
Roof material preferences for housing can be influenced from the location of the respondents, local climate, culture, knowledge and comfortable condition of the occupants. The aim of this research is to get the reasons behind the selection of roof material for housing. Quantitative method is used in this research by collecting data of online questionnaire. This online questionnaire is distributed using convenient sampling method (snowball-non-random-sampling). It was found the tendency of respondents who choose clay tile because of the comfort and affordability of the price. The tendency of respondents who choose ceramic tile and natural wood tile because of their beauty and sustaniability materials. Concrete is selected by respondents because of their durability and strength. Respondents who have tendency in Zinc, asbestos are selected because zinc and asbestos are easy to apply and commonly materials in their areas. Asphalt, metal, and PVC / galvalum / fiber are chosen by respondents for being lightweight materials.
\end{abstract}

Keywords: housing, material, preference, roof.

\begin{abstract}
Abstrak
Preferensi penggunaan material pada atap rumah berbeda-beda, dipengaruhi lokasi responden tinggal, iklim setempat, budaya bermukim, pengetahuan, ambang kenyamanan penghuninya, dll. Tujuan penelitian ini adalah mengetahui alasan yang melatar-belakangi pemilihan material menurut jenis material yang digunakan sebagai atap rumah. Penelitian ini menggunakan metode kualitatif dengan pengumpulan data kuesioner online, yang dibagikan menggunakan metode convenient sampling (snowball-non-random-sampling). Ditemukan kecenderungan responden memilih genteng tanah liat karena kenyamanan dan keterjangkauan harga. Kecenderungan responden yang memilih genteng keramik dan genteng kayu alami karena keindahan dan ramah lingkungan. Beton dipilih responden karena keawetan dan kekuatan. Seng/asbes dipilh responden karena kemudahan dan keterbiasaan. Aspal, metal, dan PVC/galvalum/fiber dipilih responden karena ringan.
\end{abstract}

Kata kunci: atap, material, preferesi, rumah.

\section{Pendahuluan}

Pembahasan mengenai arsitektur erat kaitannya dengan material bangunan (Duggal, 2008). Nilai arsitektur sebuah bangunan dapat muncul dari eskpresi material yang digunakan (Beck, 2007). Berbagai pengembangan jenis material dan bentuk material dapat terjadi karena penyesuaian terhadap konteks lingkungan dan bangunan yang dirancang (Duggal, 2008). Terlebih terhadap penggunaan material dalam skala bangunan yang bersifat privat, pemilihan penggunaan material akan dipertimbangkan mengenai kaitannya 
dengan psikologi dari penghuninya (Broto, 1997).

Material merupakan komponen
terkecil dalam bangunan. Terdapat beberapa faktor utama yang melatarbelakangi dalam pemilihan material, seperti aspek iklim, aspek ekonomi, dan pengembangan dari metode konstruksi. Penentuan jenis material yang akan diaplikasikan serta pertimbanganpertimbangan dalam menentukan material akan berdampak besar seperti pada penghematan energi, biaya, dan waktu kontruksi. Sebaliknya, apabila penggunan material kurang direncanakan dan tanpa pertimbangan akan berdampak kerugian yang besar, misalnya pengaplikasian yang lama, biaya yang membengkak yang akan berpengaruh pada proses konstruksi bangunan.

Penelitian ini membahas mengenai pemilihan material untuk atap rumah. Atap merupakan komponen yang berinteraksi secara langsung dengan matahari. Atap menerima sejumlah besar panas matahari dan mengakibatkan konsumsi energi yang berlebihan ketika tidak direncanakan melalui pemilihan material yang tepat (Jones, 2010).

Tujuan dari penelitian ini adalah untuk mengetahui alasan yang melatarbelakangi pemilihan material menurut jenis material yang digunakan pada atap rumah. Diharapkan hasil dari penelitian ini dapat memberikan manfaat kepada masyarakat luas dalam mempertimbangkan material yang akan digunakan sebagai atap rumah.

\section{Metode}

Penelitian ini menggunakan metode penelitian kualitatif yang bersifat eksploratif (Creswell, 2008; Groat \& Wang, 2002). Penelitian kualitatif eksploratif bertujuan mendapatkan data mengenai jenis atap dan alasan yang melatarbelakanginya.

\section{Metode Pengumpulan Data}

Metode pengumpulan data yang digunakan adalah kuesioner online. Kuesioner online ini dibagikan dengan menggunakan metode convenient sampling (snowball-non-randomsampling), melalui media sosial ataupun pribadi. Tidak terdapat batasan responden dari usia, lokasi tempat tinggal, pendidikan, maupun pekerjaan.

Kuesioner online berisi pertanyaan yang disusun secara kualitatif yang menggunakan struktur pertanyaan terbuka (open-ended). Pertanyaan terbuka disajikan dengan tujuan mendapatkan jawaban dari responden dengan sejujurnya tanpa adanya intervensi dari peneliti. Pertanyaan yang diajukan kepada responden antara lain:

1. Apabila anda membangun rumah, jenis material atap apakah yang akan anda pakai?

2. Mengapa anda memakai material tersebut sebagai atap?

Kuesioner online mulai disebarkan pada 27 Agustus 2017 dan berakhir pada 31 Agustus 2017. Penyebaran kuesioner online dilakukan di beberapa kota yaitu, Bandung, Bekasi, Depok, Kebumen, Jakarta, Purworejo, Surabaya, Surakarta, Wuhan, dan Yogyakarta. Didapatkan total responden sebanyak 218 orang dengan 122 orang $(58 \%)$ berjenis kelamin laki-laki dan 96 orang $(42 \%)$ berjenis kelamin perempuan. Responden berasal dari berbagai kelompok usia dengan rincian usia $17-40$ sebanyak 150 orang $(69 \%)$, usia 41-50 sebanyak 33 orang (15\%) dan usia $>50$ sebanyak 35 orang (16\%).

\section{Metode Analisis Data}

Analisis data dilakukan secara kualitatif dan kuantitatif. Analisis data kualitatif menggunakan metode analisis isi, sedangkan analisis data kuantitatif menggunakan analisis distribusi dan analisis korespondensi. Metode analisis isi dalam penelitian ini menggunakan langkah-langkah open coding, axial coding, dan selective coding (Strauss \& Corbin, 1990).

Tesa Arsitektur Volume 18| Nomor 1 | 2020 
Pertama, responden diminta untuk memilih beberapa jenis material tersedia, antara lain genteng tanah liat, genteng kayu alami (kayu/ulin/bambu), genteng keramik, beton, metal, seng/asbes, maupun material yang lain. Kemudian dilakukan analisis distribusi untuk mengetahui pilihan material yang dominan atau paling banyak dipilih.

Selanjutnya, dilakukan analisis isi dari pertanyaan terbuka untuk mengetahui alasan dari responden memilih material tersebut. Alasan tersebut yang akan dijadikan kriteria maupun preferensi material yang ideal menurut responden. Analisis isi dilakukan dengan urutan open coding, axial coding dan selective coding. Open coding dilakukan dengan mengidentifikasi kata kunci dari alasan yang diungkapkan responden. Tahapan axial coding dilakukan dengan mengkategorikan kata-kata kunci yang didapatkan dari tahap open coding. Tahapan yang terakhir adalah tahapan selective coding, merupakan proses menyusun hipotesis berdasarkan analisis korespondensi, yang mengungkapkan hubungan antara kategori material dengan preferensi material untuk atap rumah.

\section{Kajian Teori}

Atap merupakan komponen pelindung yang berada paling atas dalam sebuah rumah. Atap memiliki peran pelindung secara fisik dan psikologi. Peran atap dalam perlindungan fisik adalah melindungi dari perubahan cuaca, pergerakan angin, atau apapun yang membahayakan keselamatan penghuninya (Marshall \& Worthing, 2006). Peran atap dalam melindungi secara psikologi adalah atap berperan menciptakan kesan nyaman pada penghuni ketika di rumah. Selain bersifat sebagai pelindung, atap juga berperan penting dalam membentuk estetika arsitektur sebuah rumah (Akmal, 2009) dan memberikan insulasi kenyamanan termal yang baik (Marshall \& Worthing, 2006).
Di daerah tropis seperti Indonesia, atap merupakan elemen rumah yang memiliki urgensi yang tinggi dan mendapat prioritas yang lebih dalam bentuk maupun material penyusunnya. Maka, kualitas atap yang digunakan harus baik. Kualitas atap yang baik dapat dicapai dari kualifikasi jenis material yang digunakan, desain material, teknik pengerjaannya dan penerapannya.

Preferensi penggunaan material pada atap rumah berbeda-beda, hal ini dipengaruhi dari lokasi tempat tinggal, fenomena iklim setempat, budaya bermukim, pengetahuan, dan ambang kenyamanan dari penghuninya. Sebagai contoh, pada masyarakat yang tinggal di daerah yang berangin besar akan cenderung menggunakan material atap yang berasal dari kayu ulin atau sirap karena genteng atau material lain akan sering terjadi pergeseran posisi dan membutuhkan perawatan lebih. Menurut Frick (1999) terdapat beberapa kriteria yang harus dipertimbangkan dalam memilih material bangunan, antara lain:

a. Material memberikan pengaruh positif terhadap kesehatan dan kenyamanan penghuni.

b. Material mendukung konsep hemat energi.

c. Material bersifat ramah lingkungan.

d. Bahan material dapat digunakan kembali, maupun diolah kembali.

e. Sumber bahan bangunan dari daerah setempat dan pengolahan secara in-situ.

\section{Hasil dan Pembahasan}

Tahapan analisis isi dilakukan dengan open coding atau tahapan untuk mengidentifikasi kata kunci yang diperoleh dari data teks melalui kuesioner yang diberikan. Pada tahapan awal diberikan pertanyaan yang bersifat tertutup kepada responden mengenai material manakah yang akan digunakan sebagai bahan untuk atap rumah responden. Contoh jawaban jenis material yang dipilih responden dapat dilihat pada kutipan berikut.

Tesa Arsitektur Volume 18| Nomor 1 | 2020 
"Genteng tanah liat, Genteng Keramik, PVC/ Galvallum/ Fiber." (Swasta)

"Genteng kayu ulin/sirap/bambu." (PNS)

Contoh open coding dari jabawan responden mengenai alasan memilih material dapat dilihat pada kuitipan berikut.

\begin{abstract}
"Harganya yang relatif terjangkau, mudah dicari, tersedia beragam bentuk dan model, kuat (tetap aman meski diinjak), tahan lama (meski cuaca Indonesia yang cepat sekali berubahubah seperti panas, dingin dan hujan), aman terhadap serangan serangga, mudah pemasangannya dan harus dilapisi cat agar tidak berjamur." (Mahasiswa)

"Cocok untuk iklim tropis di Indonesia serta material tersebut yang paling banyak digunakan pada bangunan rumah di Indonesia." (Arsitek)
\end{abstract}

Berdasarkan paparan di atas, diperoleh beberapa kata kunci dari alasan memilih material atap rumah yaitu "murah", "mudah didapat", "desain beragam", "awet", "merespon iklim", dan "umum digunakan".

Setelah melalui tahapan open coding, selanjutnya dilakukan pengelompokan kata kunci (axial coding). Pengelompokan kata kunci dilakukan melalui diskusi kelompok untuk menghindari hasil yang terlalu subjektif atau bias. Ditemukan total 9 kategori untuk alasan pemilihan material atap rumah. Berikut dipaparkan mengenai contoh axial coding pemilihan material untuk atap rumah dari responden.
Tabel 1. Contoh axial coding alasan memilih material. (Sumber: Analisis pribadi, 2017)

\begin{tabular}{ccc}
\hline No & Kata kunci & Kategori \\
\hline 1 & Murah & $\begin{array}{c}\text { Keterjangkauan } \\
\text { harga }\end{array}$ \\
\hline 2 & $\begin{array}{c}\text { Ramah } \\
\text { lingkungan }\end{array}$ & $\begin{array}{c}\text { Ramah } \\
\text { lingkungan }\end{array}$ \\
\hline & $\begin{array}{c}\text { Mereduksi } \\
\text { panas }\end{array}$ \\
& $\begin{array}{l}\text { Merespons } \\
\text { iklim }\end{array}$ & \\
3 & Kenyamanan \\
& $\begin{array}{l}\text { Meredam } \\
\text { kebisingan }\end{array}$ \\
& $\begin{array}{l}\text { Kontekstual } \\
\text { arsitektur } \\
\text { lokal }\end{array}$ \\
&
\end{tabular}

\section{Jenis material dan Alasan Pemilihannya}

Melalui pengkategorian kata kunci, diperoleh 9 kategori yang mewakili jawaban responden sebagai data pengolahan analisis distribusi. Analisis frekuensi dilakukan dengan analisis distribusi, di mana data teks dari responden yang terakumulasi akan menunjukkan jawaban yag paling dominan dan yang tidak dominan. Hasil analisis distribusi pilihan jenis material atap dan alasan responden memilihnya dapat dilihat pada Diagram 1 dan Diagram 2. 


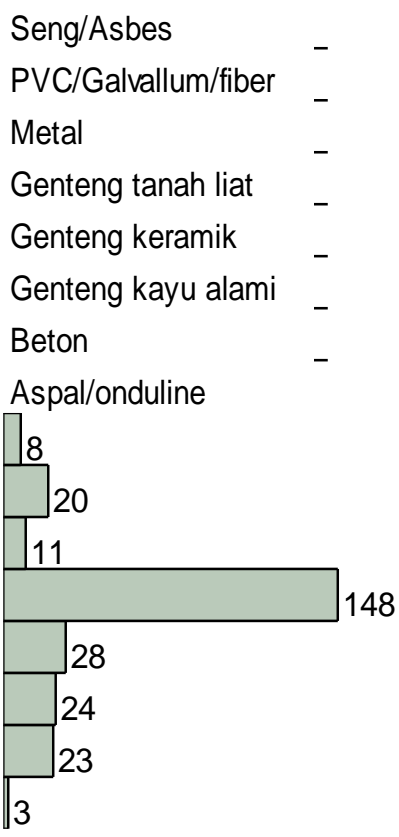

Diagram 1. Analisis distribusi jenis material atap rumah tropis. (Sumber: Analisis pribadi, 2017)

Hasil ini menunjukkan bahwa genteng tanah liat menjadi pilihan utama responden dalam penggunaan material penyusun atap di lingkungan tropis dan yang paling sedikit dipilih adalah genteng aspal/onduline. Hasil analisis distribusi untuk alasan dalam memilih material tersebut dapat dilihat pada Diagram 3.

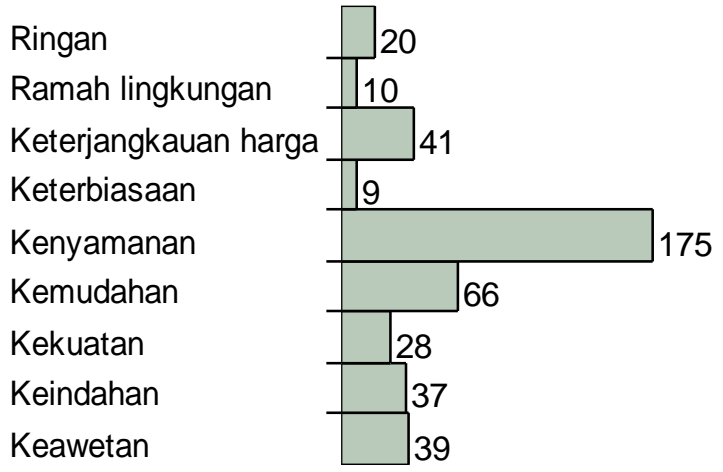

Diagram 2. Analisis distribusi alasan memilih material. (Sumber: Analisis pribadi, 2017)

Hasil analisis distribusi alasan memilih material menyatakan bahwa kenyamanan merupakan alasan dominan utama bagi responden. Menurut responden, alasan tersebut dilatar-belakangi oleh beberapa faktor, antara lain mereduksi panas matahari ketika siang hari, merespon iklim tropis, meredam kebisingan yang berasal dari lingkungan misalnya jalan raya ataupun polusi udara yang lain, dan kontekstual terhadap arsitektur lokal.

Selanjutnya, alasan pendukung pemilihan material terdiri dari alasan mudah didapatnya material tersebut di lingkungan sekitar responden, mudah diaplikasikannya material tersebut dalam proses pembangunan, pemeliharaan atau perawatan material yang minimal, praktis dan fleksibel dalam penerapan. Alasan keterbiasaan penggunaan material, banyaknya penggunaan material di lingungan sekitar responden, serta ramah lingkungan merupakan alasan yang paling kecil diutarakan. Data tersebut menunjukkan bahwa kenyamanan merupakan alasan utama yang memiliki tingkat urgensi paling tinggi dalam pertimbangan setiap unsur rumah sebagai kebutuhan primer bagi manusia.

\section{Korespondensi Jenis Material dan Alasan Pemilihannya}

Analisis selanjutnya dalam penelitian ini adalah selective coding yang dilakukan melalui analisis korespondensi. Analisis korespondensi memiliki tujuan untuk mengetahui hubungan antara jenis material atap yang dipilih dengan alasan pemilihan material tersebut. Analisis korespondensi dilakukan dengan menggunakan ward hierarchial clustering, yang hasilnya dapat dilihat pada Gambar 1. Ditemukan nilai signifikansi sebesar $p=$ $<.0001$ yang menunjukkan alasan pemilihan material dan jenis material atap memiliki hubungan yang sangat kuat (sangat signifikan berhubungan). 
$\square$ Aspal / Onduline (3)

-Ringan (20)

$\square$ Metal (11)

口PVC/ Galvallum/ Fiber (20)

口Beton (23)

- Keawetan (39)

-Kekuatan (28)

$\square$ Genteng kayu alami (24)

- Keindahan (37)

Ramah lingkungan (10)

口Genteng keramik (28)

$\square$ Genteng tanah liat (148)

-Kenyamanan (175)

-Keterjangkauan Harga (41)

口Seng/asbes (8)

Kemudahan (66)

-Keterbiasaan (9)

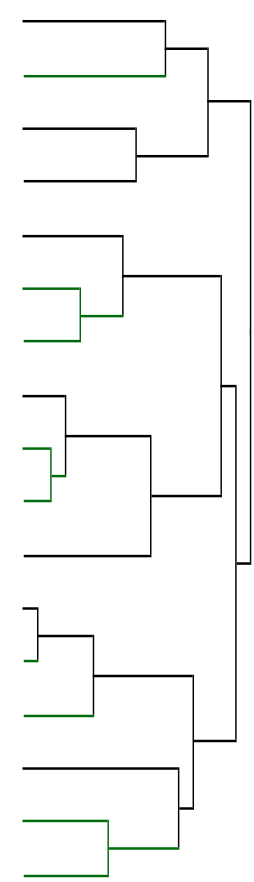

Diagram 3. Dendrogram hasil analisis korespondensi antara alasan memilih material dan jenis material yang dipilih. (Sumber: Analisis pribadi, 2017)

Model hipotesis yang menunjukkan pengelompokan material dan karakteristik/ kualitas material hasil analisis korespondensi digambarkan pada diagram di bawah (Gambar 1).
Kelompok material kerajinan lokal/konvensional
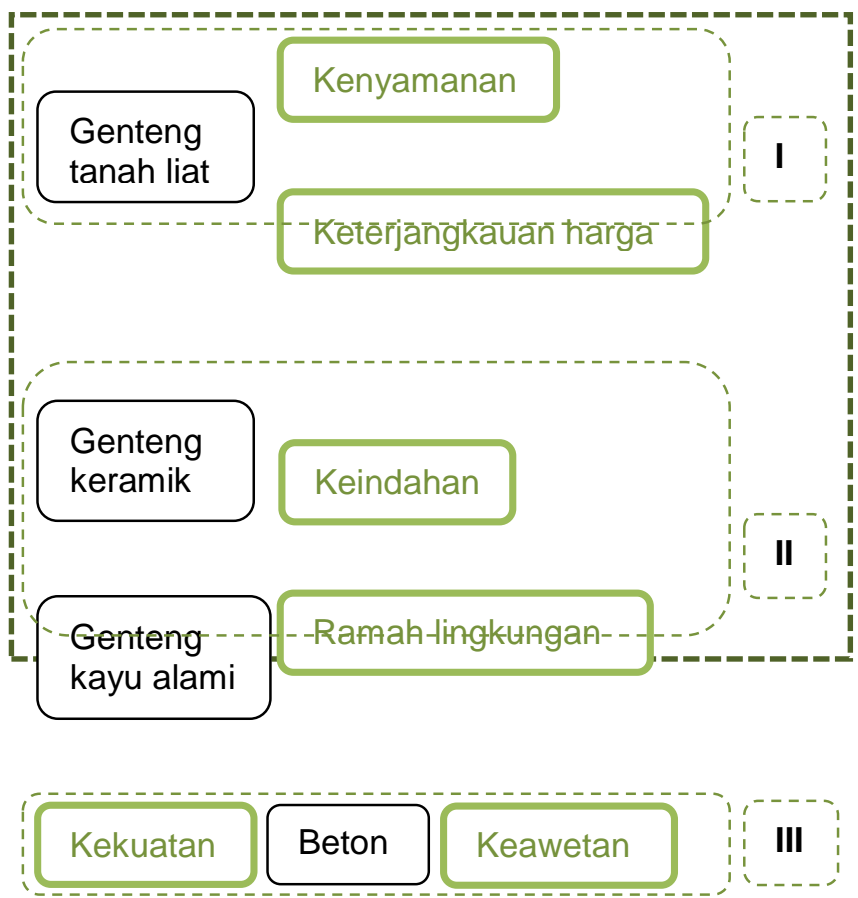

Kelompok material hasil industri

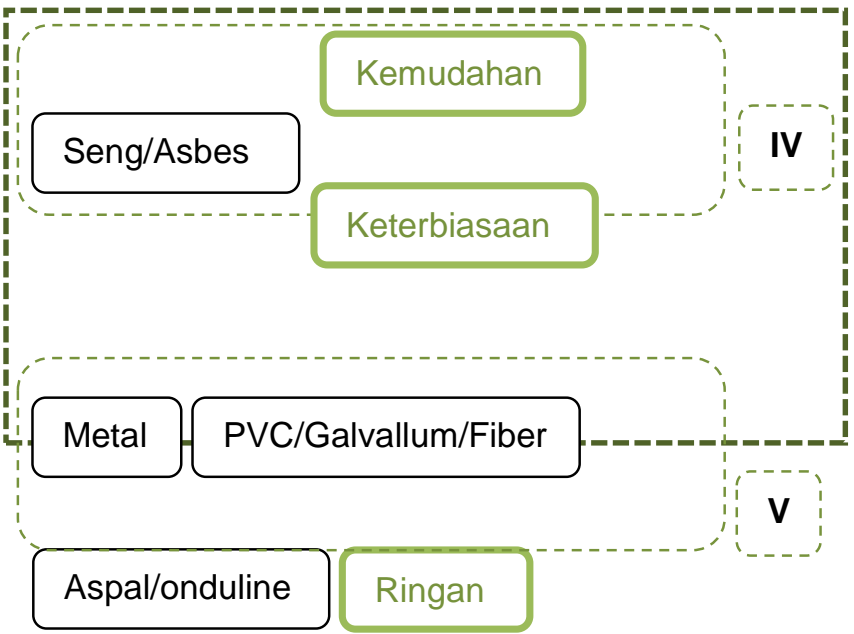

Gambar 1. Pola kedekatan antara alasan memilih material dengan material yang dipilih. (Sumber: Analisis pribadi, 2017)

\section{Kelompok Material I}

Genteng tanah liat dipilih oleh responden karena kenyamanan dan keterjangkauan harga. Kenyamanan

Tesa Arsitektur Volume 18| Nomor 1 | 2020 
dipengaruhi oleh alasan kemampuan material yang dinilai mereduksi panas, merespons iklim setempat, meredam kebisingan yang berasal dari lingkungan, dan kontekstual terhadap arsitektur lokal.

Hal tersebut sejalan dengan Pernyataan Ferrari (2014) bahwa genteng tanah liat merupakan material atap yang telah digunakan secara luas karena kemampuan mekanisnya sebagai material yang baik. Genteng tanah liat sebagai pelindung bangunan melindungi paparan sinar matahari, polutan, asap, dengan memantulkan kembali ke lingkungan luar melalui permukaannya sehingga mengkondisikan kenyamanan pada penghuni.

Mengenai kecenderungan responden terhadap keterjangkauan harga, tidak sejalan dengan pernyataan Marshall \& Worthing (2006) yang menyatakan bahwa genteng tanah liat yang dibuat oleh industri pabrikasi lokal termasuk material penutup atap yang mahal. Hal tersebut dinilai dari proses pengerjaan dan bahan bakunya. Meskipun dari sejarah pemakaiannya material tersebut telah digunakan secara luas di belahan dunia sejak abad ke-19.

\section{Kelompok Material II}

\section{Genteng}

kayu alami (ulin/sirap/bambu) dan genteng keramik dilipih responden karena keindahan dan ramah lingkungan. faktor dari keindahan adalah material tersebut dinilai estetis, memunculkan ekspresi material alam, dan memiliki desain yang beragam. Kecenderungan responden tersebut sejalan dengan teori yang dikemukakan oleh Farrelly (2006) bahwa material kayu alami merupakan material yang indah, mengekspresikan kesan natural, dan termasuk dalam material berkelanjutan. Bahan baku dari kayu alami dapat dikembangbiakkan kembali dan penerapannya tidak menyebabkan sampah ke lingkungan sehingga dinilai juga sebagai material ramah lingkungan.

Farrelly (2006) juga menyebutkan bahwa material kayu alami dapat diberlakukan finishing yang beraneka TERAKREDITASI : 36/E/KPT/2019 macam, seperti diampelas, dihaluskan, diwax, difurnish, diberikan warna maupun cat. Teknik finishing dari kayu alami adalah fleksibel, sesuai dengan olah rasa, desain, dan aplikasi dari penggunanya. Pernyataan tersebut mendukung kecenderungan responden yang menyebutkan bahwa material kayu alami memiliki desain yang beragam.

Selanjutnya, mengenai kecenderungan responden memilih genteng keramik sebagai atap karena keindahan juga sejalan dengan teori yang dikemukakan oleh Mehta et al. (2013) bahwa genteng keramik merupakan material yang indah, karena banyaknya variasi warna dan desain yang dipasarkan. Mehta et al. (2013) juga menyebutkan bahwa keindahan yang dimiliki genteng keramik juga didukung oleh durabilitasnya yang menyamai genteng batu, yang banyak diterapkan di Eropa dan Amerika.

\section{Kelompok Material III}

Beton dipilih oleh responden karena kekuatan dan keawetan dari material tersebut dalam menerima beban, ketahanan waktu dari material tersebut diterapkan dan ketahanan terhadap pergantian cuaca. Atap beton yang dimaksud dalam penelitian ini adalah berupa atap datar yang terbuat dari beton maupun atap beton unit (masonry materials).

Kecenderungan konsumen tersebut sejalan dengan teori yang dikemukakan oleh Allen \& Iano (2009) bahwa beton merupakan material yang memiliki durabilitas tinggi, yang dapat digunakan sebagai material konstruksi bangunan, termasuk atap, yang bersifat tahan lama dan dapat disesuaikan berbagai kebutuhan. Prianto \& Dwiyanto (2013) juga menyebutkan mengenai nilai durabilitas beton bahwa penggunaannya dapat bertahan 30 hingga 40 tahun.

\section{Kelompok Material IV}

Aspal/onduline, metal, dan PVC/Galvallum/ fiber dipilih responden karena ringan sehingga berdampak struktur konstruksi yang diterapkan praktis,

Tesa Arsitektur Volume 18| Nomor 1| 2020 
cepat dikerjakan, dan mudah dalam pengangkutan menuju lokasi proyek. Kecenderungan responden dalam memilih jenis atap tersebut berdasar berat material yang ringan sejalan dengan beberapa teori berikut.

Kecenderungan responden yang memilih atap aspal karena ringan adalah sejalan dengan teori Mehta et al. (2013) yang menyebutkan bahwa kelebihan atap aspal adalah bobotnya yang ringan, sehingga berdampak memperkecil usaha pengangkutan dan pengaplikasian, mereduksi beban transportasi dan biaya dari komponen atap secara keseluruhan. Selain itu, atap aspal merupakan jenis atap yang terjangkau dari segi harga dan tahan lama dari segi pengaplikasiannya. Aspal merupakan material yang murah, cepat dalam pemasangan, tahan terhadap api, dan memiliki daya tahan hingga 15 sampai 25 tahun (Allen \& lano, 2009).

\section{Kecenderungan}

responden menyebutkan alasan ringan pada metal sejalan dengan teori Allen \& lano (2009) bahwa atap metal merupakan atap yang mudah dan praktis untuk diaplikasikkan karena beratnya yang ringan dan sambungannya yang sederhana. Atap metal juga memiliki kelebihan perawatan yang minimal serta dapat diolah kembali setelah bangunan di hancurkan. Atap metal yang dijual dipasaran dapat berbentuk lembaran ataupun panel yang siap dipasang. Begitu juga pada material PVC/Galvallum/Fiber, teori Allen \& lano (2009) menyebutkan bahwa matereial tersebut ringan dan mudah diaplikasikan. Oleh karena itu, kecenderungan responden adalah tepat.

\section{Kelompok Material V}

Seng/asbes dipilih
keterbiasaan dan kemudahan dalam
pengaplikasian. Alasan dari kemudahan
yang dikemukakan responden adalah
penerapan material tersebut mudah,
praktis dan fleksibel. Responden juga
menilai bahwa kemudahan juga termasuk
alasan material tersebut mudah
didapatkan, serta pada masa pengunaan,
material tersebut tidak banyak
membutuhkan perawatan. Keterbiasaan
TERAKREDITASI : $36 / \mathrm{E} / \mathrm{KPT} / 2019$
ISSN cetak 1410-6094 | ISSN online 2460-6367 yang dimaksud adalah material tersebut umum digunakan di lingkungan sekitar responden.

Kecenderungan responden mengenai kemudahan sejalan dengan pernyataan yang dikemukakan oleh Setijanti et al. (2012) bahwa atap seng mudah dari segi teknis pengaplikasian, efisien dari segi waktu pelaksanaan, terjangkau dari segi harga dan mengalirkan air hujan dengan baik. Mengenai keterbiasaan, Setijanti et al. (2012) menyebutkan bahwa material yang telah dikenal oleh masyarakat hingga terjadi penerapan yang luas memunculkan persepsi bahwa material tersebut bagian dari budaya hasil kesepakatan komunitas, sehingga umum digunakan.

\section{Penutup}

\section{Kesimpulan dan Saran}

Setelah melakukan seluruh tahapan analisis, ditemukan bahwa preferensi material atap bagi rumah tropis adalah genteng tanah liat dengan alasan kenyamanan. Juga ditemukan bahwa material aspal/onduline memang kurang diminati oleh masyarakat Indonesia. Hal ini dikarenakan material tersebut memang kurang dikenal oleh sebagian masyarakat, terlebih masyarakat juga mengutamakan segi lokalitas dari material yang diaplikasikan.

Disimpulkan bahwa material yang berasal proses industri kerajinan masyarakat lokal serta bahan dasar dari alam dinilai responden lebih mengakomodasi kebutuhan hunian masyarakat tropis Indonesia seperti, meningkatkan kenyamanan, estetika, ketahanan terhadap cuaca dan waktu, ramah lingkungan, dan terjangkau. Material yang berasal dari proses industri pabrikasi dinilai masyarakat mengakomodasi terhadap kemudahan proses konstruksi, seperti ringan, kemudahan dalam pengaplikasian, dan penekanan biaya konstruksi.

Kekurangan penelitian ini adalah distribusi responden kurang menyeluruh di Tesa Arsitektur Volume 18| Nomor 1 | 2020 
berbagai kota di Indonesia. Namun, hasil penelitian sudah cukup valid karena memiliki tingkat signifikan diatas 95\%, atau tingkat kesalahan kurang dari $5 \%$. Diharapkan hasil penelitian ini dapat digunakan sebagai kriteria maupun acuan yang digunakan oleh perancang, pengembang, maupun penyedia material untuk mengakomodasi kebutuhan mupun keinginan penghuni dalam mewujudkan rumah dengan atap yang sesuai untuk lingkungan tropis.

\section{Daftar Pustaka}

Akmal, I. (2009). Seri Rumah Ide Edisi 7/IV: Atap dan Kanopi. Jakarta: Gramedia Pustaka Utama.

Allen, Edward \& Iano, Joseph. (2009). Fith Edition Fundamentals of Building Construction Material and Methods. New Jersey: John Wiley \& Sons.

Allott, D. (1987). Housing materials and construction. BSAP Occasional Publication, 11, 59-62.

Beck, R. A. J. (2007). The Durable House: House Society Models in Archaeology. Illinois: Center for Archaeological Investigations, Southern Illinois University.

doi:10.1017/CBO9781107415324.004

Broto, Carles. (1997). Architectural Design Houses. Gravina: Instituto Monsa de Ediciones.

Creswell, J.W. (2008). Research Design: Qualitative, Quantitative, and Mixed Methods Approaches. California: Sage Publications, Inc.

Duggal, S.K. (2008). Building Materials. New Delhi: New Age International $(P)$ Limited, Publishers.

Farrelly, Lorraine. (2006). Basic Architecture Construction and Materiality. Switzerland: AVA Publishing SA.
Ferrari, Chiara, et.al. (2014). Effect of aging processes on solar reflectivity of clay roof tiles. France: Journal Advances in Building Energy research Vol. 8. http://www.tandfonline.com/doi/abs/10. 1080/17512549.2014.890535

Frick, H. \& Ch. Koesmartadi. (1999). Ilmu Bahan Bangunan Eksploitasi, Pembuatan, Penggunaan dan Pembuangan. Semarang: Kanisius.

Groat, L. \& Wang, D. (2002). Architectural Research Methods. New York: John Wiley \& Sons. Inc.

Harries, Kent \& Bhavna Sharma. (2016). Nonconventional and Vernacular Construction Materials. Cambridge, MA: Woodhead Publishing.

Kumar, R. (2011). Research Methodology. London: Sage Publications Ltd.

Marshall, D \& Worthing, D. (2006). The Construction of Houses. Glasgow: Bell \& Bain Ltd.

Mehta, M; Scarborough, W; \& Armpriest, D. (2013). Building Construction Principles, Materials, and Systems Second Edition. Boston: Pearson.

Prianto, E. \& Dwiyono, A. (2013). Profil Penutup Atap Genteng Beton dalam Efisiensi Konsumsi Energi Listrik pada Skala Rumah Tinggal. Semarang: Modul Universitas Diponegoro Vol. 13 No.1 Januari-Juni 2013.

Setijanti, et al. (2012). Eksistensi Rumah Tradisional Padang dalam Menghadapu Perubahan Iklim dan Tantangan Jaman. Simposium Nasional RAPI XI Fakultas Teknik UMS. ISSN: 1412-9612. 